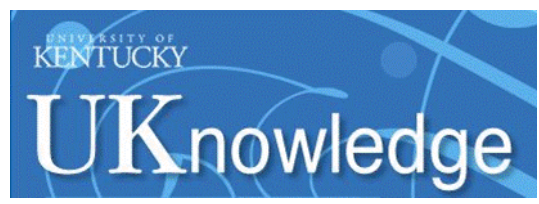

University of Kentucky

UKnowledge

\title{
Proposed Crowdfunding Regulations Under the Jobs Act: Please, SEC, Revise Your Proposed Regulations in Order to Promote Small Business Capital Formation
}

Rutheford B. Campbell Jr.

University of Kentucky College of Law, rcampbel@uky.edu

Follow this and additional works at: https://uknowledge.uky.edu/law_facpub_advocacy

Part of the Securities Law Commons

Right click to open a feedback form in a new tab to let us know how this document benefits you.

\section{Repository Citation}

Campbell, Rutheford B. Jr., "Proposed Crowdfunding Regulations Under the Jobs Act: Please, SEC, Revise Your Proposed Regulations in Order to Promote Small Business Capital Formation" (2014). Law Faculty Advocacy. 4.

https://uknowledge.uky.edu/law_facpub_advocacy/4

This Correspondence is brought to you for free and open access by the Law Faculty Publications at UKnowledge. It has been accepted for inclusion in Law Faculty Advocacy by an authorized administrator of UKnowledge. For more information, please contact UKnowledge@lsv.uky.edu. 


\section{Proposed Crowdfunding Regulations Under the Jobs Act: Please, SEC, Revise Your Proposed Regulations in Order to Promote Small Business Capital Formation}

\section{Notes/Citation Information}

Letter from Rutheford B Campbell, Jr., Professor, to Elizabeth M. Murphy, Secretary, U.S. Securities and Exchange Commission (February 14, 2014) (submitted electronically to rule-comments@sec.gov). 
PROPOSED CROWDFUNDING REGULATIONS UNDER THE JOBS ACT: PLEASE, SEC, REVISE YOUR PROPOSED REGULATIONS IN ORDER TO PROMOTE SMALL BUSINESS CAPITAL FORMATION

\author{
Rutheford B Campbell, Jr. \\ Spears-Gilbert Professor of Law \\ University of Kentucky College of Law \\ Lexington, Kentucky \\ (859) 257-4050 \\ rcampbel@uky.edu
}




\begin{abstract}
The Jobs Act was enacted to promote efficient access to external capital by small businesses. Title III of the Jobs Act offers small businesses the chance of efficient financial intermediation through crowdfunding. The crowdfunding exemption is not self-executing but, instead, requires regulatory implementation by the SEC.

The Commission's first iteration of its crowdfunding rules fails to offer small businesses efficient access to external capital. Principally, this is because the proposed crowdfunding rules: (1) require excessive disclosures, especially regarding smaller crowdfunding offerings; (2) fail to offer small businesses relying on the crowdfunding exemption two-way safe harbor integration protection; and (3) fail to protect small businesses from the loss of the crowdfunding exemption as the result of the financial intermediary's failure to meet its statutory and regulatory obligations.

The problems can be fixed by the Commission by revising its proposed crowdfunding regulations, thereby fulfilling its broad and ubiquitous obligation to balance capital formation and investor protection.
\end{abstract}


February 14, 2014

\title{
Submitted electronically to rule-comments@sec.gov
}

\author{
Elizabeth M. Murphy \\ Secretary \\ U.S. Securities and Exchange Commission \\ $100 \mathrm{~F}$ Street, NE \\ Washington, DC 20549
}

\section{Re: Rulemaking under Title III of the Jobs Act}

Dear Ms. Murphy:

I write to offer comments on the proposed crowdfunding regulations implementing Title III of the Jobs Act (the Crowdfunding Act), as announced in the Commission's Release 33-9470 (Oct. 23, 2013) .

\section{A. Overview of My Comments}

Title III of the Jobs Act, the Crowdfunding Act, is intended to provide a statutory structure within which small companies are able to raise a relatively modest amount of capital through unregistered offerings conducted over the internet.

The fundamentals of the Crowdfunding Act are sound. The Act offers the Commission the opportunity to construct a new exemption from registration that may enable small businesses to solicit broadly and efficiently for external capital through the use of modern technology. The Act provides the Commission a rational (albeit challenging) framework for a disclosure regime that balances the capital formation needs of small issuers with the need for investor protection in connection with the offering of securities. The Act does not, either as a matter of language or practical effect, limit investors to accredited investors, and the Act enables small businesses to solicit for external capital free from the debilitating effect of state registration laws and regulations.

The Crowdfunding Act delegates broad authority to the Commission to implement the Act through regulations.

For the Commission's crowdfunding regulations to work - to provide an appropriate access to external capital for small businesses - relative offering costs (offering costs as a percentage of proceeds from the offering) in crowdfunding transactions must be at a level that is rational and economically efficient. High relative offering costs will simply price the crowdfunding exemption out of reach for small 
businesses. $^{1}$

The Commission has now promulgated its first iteration of proposed crowdfunding regulations, ${ }^{2}$ and I fear those regulations fail to offer small businesses an efficient and balanced regulatory exemption. revision:

Three parts of the proposed crowdfunding regulations need attention and

(1) The required ex ante disclosures (disclosures required at the time of the crowdfunding offering) and the required ex post disclosures (disclosures required subsequent to the crowdfunding offer) must be reduced, especially in the case of small crowdfunding offerings (e.g., offerings of less than $\$ 500,000$ ).

(2) The crowdfunding exemption must be protected from integration by a two-way safe harbor regulation.

(3) Issuers should not be at risk to loose the crowdfunding exemption because of an intermediary's failure to meet its statutory or regulatory obligations.

Without these adjustments the purpose of the Crowdfunding Act - which is to provide small businesses with efficient and low cost financial intermediation in a setting that offers appropriate levels of protection to investors - will not be accomplished. Without adjustments, relative offering costs will foreclose many small businesses from using the crowdfunding exemption for small offerings.

\section{B. Revision of Disclosure Obligations}

Setting the efficient level of mandatory disclosure for the crowdfunding exemption is certainly the most difficult decision for the Commission in connection with its crowdfunding regulations.

There are two disclosure obligations in the proposed crowdfunding regulations: the ex ante obligation, which is the obligation to provide investment information at the point of offer and sale, and the ex post obligation, which is the obligation to provide continuing information after the offering is completed.

Considering first the ex ante disclosure obligations, one finds, depending on how

${ }^{1}$ It is relative offering costs that preclude small issuers from accessing external capital. Relative offering costs are offering costs compared to the total size of the offering. To use extreme examples, offering costs of $\$ 100,000$ will preclude a company from offering a total of $\$ 100,000$ in its securities. Offering costs of $\$ 100,000$, however, will not preclude a company from offering $\$ 50$ million in its securities. Because the capital needs of small businesses are small, relative offering costs are necessarily high and thus more likely to preclude a small business from acquiring external capital.

${ }^{2}$ Crowdfunding, 78 Fed. Reg. 66,428 (Nov. 5. 2013) (to be codified at 17 CFR pts. 200,227, 232, 239 and 249). 
one counts, that the proposed crowdfunding regulations require issuers to provide the Commission and investors with approximately twenty categories of financial and nonfinancial investment information. ${ }^{3}$ I see in these requirements soaring relative offering costs - especially for offerings of less than $\$ 500,000$ - generated by the amount and, at least in some cases, the nature of information that is required to be disclosed and by the practical necessity of the issuer's engaging expensive professionals in constructing the required disclosures. In short, I am unable in the case of small offerings to find in the proposed crowdfunding regulations an efficient regulatory balance between small business capital formation and investor protection.

The sheer volume, detail and practical complexity of this ex ante disclosure of information is perhaps even more vivid and thus daunting when viewed through the lens of one who has written disclosure documents required by the Securities Act of 1933 and the Securities Act of 1934. A few of examples out of the twenty or so categories of information will illustrate this point. Risk factors must be disclosed, ${ }^{4}$ and initially identifying the issuer's risk factors and constructing the required disclosures is a matter that necessarily will involve significant time from the issuer's counsel. ${ }^{5}$ Required disclosures about "ownership and capital structure" are especially challenging. ${ }^{6}$ Six separate disclosures are required, including how the rights of principal shareholders could impact crowdfunding investors, "[h]ow the [crowdfunding] securities . . . are being valued, and examples of methods for how such securities may be valued by the issuer in the future, including subsequent corporate actions," risks of minority ownership. ${ }^{9}$ Finally, there is the obligation for a narrative "description

${ }^{3} 17$ C.F.R. $\S 227.201(a)-(v)(2013)$.

${ }^{4} 17$ C.F.R. $\S 227.201(f)(2013)$.

${ }^{5}$ One practical point regarding the costs of meeting the crowdfunding disclosures should be made. It is likely a small business utilizing the crowdfunding exemption will be an unseasoned issuer - one that for the first time is preparing offering documents required by securities regulators. This makes it likely that outside counsel will literally draft the whole of the disclosures rather than - as is typical in an offering by a seasoned issuer - merely reviewing the work of the issuer itself. This significantly increases attorney fees for the crowdfunding issuer. Drafting risk disclosures provides an example of this. A seasoned issuer, one for example that is reporting under the Securities Exchange Act of 1934, can simply update and revise as necessary its "Risk Factors" section from a prior Commission filing. Such a low cost disclosure is impossible in a crowdfunding offering.

${ }^{6} 17$ C.F.R. $\S 227.201(\mathrm{~m})(2013)$.

${ }^{7} 17$ C.F.R. $\S 227.201(\mathrm{~m})(2)(2013)$.

${ }^{8} 17$ C.F.R. $§ 227.201(\mathrm{~m})(4)$ (2013). This disclosure will involve complex present value calculations and an understanding and disclosure of future reorganizations and how such transactions may impact shareholder wealth.

${ }^{9} 17$ C.F.R. $\S 227.201(\mathrm{~m})(5)$ (2013) requires disclosure of "[t] ownership in the issuer and the risks associated with corporate actions including additional issuances of securities, issuer repurchases of securities, a sale of the issuer or of assets of the issuer or transactions with related parties." 
of the financial condition of the issuer," ${ }^{10}$ a requirement that seems to be a first cousin to the "Management's Discussion and Analysis"11 required, for example, in Form 10-Ks that are filed under the Securities Exchange Act of $1934 .^{12}$

The ex ante disclosures required by the proposed crowdfunding regulations also include financial statements. ${ }^{13}$ The financial statements provided to investors and the Commission must "[i]nclude a balance sheet, income statement, statement of cash flows and statement of changes in owners' equity and notes to financial statements prepared in accordance with U.S. generally accepted accounting principles," and the financial statements must cover at least two years or since the inception of the company. ${ }^{14}$ The Commission's crowdfunding regulations, consistent with the Crowdfunding Act, ${ }^{15}$ offer a modest stepped approach to the certification or audit requirements of these financial statements. For offerings of $\$ 100,000$ or less, the statements must be "certified by the principal executive officer of the issuer to be true and complete in all material respects;" for offerings between $\$ 100,000$ and $\$ 500,000$, the statements must be "reviewed by a public accountant who is independent of the issuer," and for offerings between $\$ 500,000$ and $\$ 1,000,000$, the financial statements must be "audited by a public accountant who is independent of the issuer". ${ }^{16}$

The burden of the foregoing ex ante required narrative and financial disclosures is significantly increased by the obligation in the proposed crowdfunding regulations ${ }^{17}$ for the issuer to provide ex post disclosures - extensive and protracted post-offering disclosures that seem modeled on the periodic disclosures under the Securities Exchange Act of 1934. These ex post disclosures raise total offering costs and may, in fact, be the most daunting of all disclosures for small businesses seeking to use the crowdfunding exemption. Essentially, the issuer is required annually to provide all the information - including financial information - required ex ante at the point of offering, except for information about the nature and terms of the original offering. ${ }^{18}$ This

\footnotetext{
${ }^{10} 17$ C.F.R. $§ 227.201(\mathrm{~s})(2013)$.

${ }^{11} 17$ C.F.R. $\$ 229.303$ (2013).

${ }^{12} 17$ C.F.R. $\S 249.310$, Item 7 (2013).

${ }^{13} 17$ C.F.R. $\S 227.201(t)(2013)$.

${ }^{14} 17$ C.F.R. $§ 227.201(\mathrm{t})($ Instr. 2) (2013).

${ }^{15} 15$ U.S.C. $\S 77 \mathrm{dA}(\mathrm{b})(1)(\mathrm{D})(2013)$.

${ }^{16} 17$ C.F.R. $§ 227.201(t)(1)-(3)(2013)$.
}

${ }^{17}$ The Crowdfunding Act delegates broad authority to the Commission to dictate the terms of this annual reporting obligation. 15 U.S.C. $\S 77 \mathrm{dA}(\mathrm{b}) 4)(2013)$ (obligation to file such annual reports "as the Commission shall by rule determine appropriate, subject to such exceptions and termination dates as the Commission may establish, by rule ....").

$$
{ }^{18} 17 \text { C.F.R. } \S 227.202(a)(2013) \text {. }
$$


periodic reporting may go on forever. ${ }^{19}$

It is difficult to see how any small issuer would knowingly agree to such terms. It is even more difficult to see any policy supporting such an extensive and protracted obligation. In short, the ex post disclosure obligations are significantly out of balance.

The purpose here is not to provide a detailed, section by section analysis of the disclosure requirements for a crowdfunding offering. The purpose, instead, is to provide a few of the more glaring examples of the Commission's loss of balance in its crowdfunding regulations.

The Commission in its first iteration of its crowdfunding regulations has failed to appreciate the impact on small issuers of the relative offering costs generated by the crowdfunding disclosure obligations.

For the new crowdfunding exemption to work, the Commission must step these disclosure requirements, requiring less disclosures for small crowdfunding offerings and more disclosures for larger crowdfunding offerings. Absent such a stepped approach, the crowdfunding exemption will be functionally unavailable for many offerings. Especially adversely impacted by the failure of the Commission to adopt such a stepped approach will be offerings by small businesses with small external capital needs, which seems exactly counter to the whole purpose of the Jobs Act.

\section{Integration Safe Harbor}

Another cost for issuers relying on the crowdfunding exemption is in the nature of an opportunity cost and is principally the result of the impact of that old and sinister concept of integration. ${ }^{20}$

The terms of the Crowdfunding Act require that the "issuer . ... shall .. . not advertise the terms of the offering, except for notices which direct investors to the funding portal or broker."21 The proposed crowdfunding regulations reiterate this statutory prohibition, limiting the issuer's right to communicate with investors to "communication channels provided by the intermediary on the intermediary's platform . . .."22

On its face, this limitation seems consistent with the balance struck by the crowdfunding exemption. Part of the investor protection for crowdfunding investors is

${ }^{19} 17$ C.F.R. $\S 227.202$ (b) (2013) (issuer is obligated to continue the annual filing until the issuer becomes a reporting company under the 1934 Act, the issuer or a third party purchases all the securities issued in the crowdfunding offering, or the issuer dissolves itself).

${ }^{20}$ See Rutheford B Campbell, Jr., The Overwhelming Case for Elimination of the Integration Doctrine Under the Securities Act of 1933, 89 KY. L. J. 289 (2001) (hereinafter, Campbell, Integration Doctrine).

${ }^{21} 15$ U.S.C. $\S 77 \mathrm{dA}(b)(2)(2013)$.

${ }^{22} 17$ C.F.R. $\S 227.204(c)(2013)$. 
this limit on aggressive selling efforts by the intermediary or the issuer. The Act and the crowdfunding regulations, therefore, essentially limit permissible selling efforts to the electronic posting of the offering and providing potential investors with disclosures of prescribed investment information.

The problem with this, however, is that this tough limitation on selling strategies, when considered together with the integration doctrine, may generate significant opportunity costs for an issuer attempting to utilize the crowdfunding exemption. In essence, it forecloses a small business issuer utilizing the crowdfunding exemption from the opportunity to market its securities in face-to-face transactions, even with local, accredited potential investors.

Consider, for example, a situation in which an issuer needs to raise $\$ 1$ million in external capital. If the issuer undertakes a crowdfunding offering in that case, it could not engage in any face-to-face selling efforts with potential investors in the issuer's community. To do so would likely be contrary to the limitation on selling efforts, described above. Even if all the local potential investors were, for example, accredited investors and thus qualified as investors under Rule 506, offering and selling shares to such accredited investors would likely violate Section 5 of the 1933 Act and destroy the crowdfunding exemption as well. The reason is because of the integration doctrine. It seems certain that the two components of the $\$ 1$ million dollar offering - the part of the offering sold on the internet through the crowdfunding exemption and the part of the offering sold in face-to-face transactions to accredited investors - would be integrated. ${ }^{23}$ If that happens, the integrated offering would meet neither the requirements of the crowdfunding offering - since the issuer would seem to violate the crowdfunding prohibition against advertising - nor the requirements for the exemption provided by Rule 506 - since the offering would include sales to unaccredited investors over the internet.

The result of this for the small business issuer is that it would have to choose between an internet offering and a face-to-face offering, and that would be a significant disadvantage for a small business struggling to raise capital. Importantly, requiring the issuer to choose between crowdfunding and a Rule 506 offering advances no economic or social policy, such as investor protection.

Integration, as I have argued in prior articles, has never made any sense. If a crowdfunding offer is made, the bases for an exemption from registration are disclosures and the limitation on aggressive selling techniques. The fact that at the same time the issuer is also engaged in selling securities to accredited investors under Rule 506 in no way harms or compromises the underlying policy of the crowdfunding exemption. Nor do the crowdfunding sales compromise the underlying policy of the exemption provided by Rule 506, which is primarily based on the fact that all

${ }^{23}$ Regulation D has its own integration safe harbor. 17 C.F.R. $\S 230.502$ (a) (2013). That safe harbor, however, offers only one way protection. That is, it protects only the Regulation D offering and not, in the case I am hypothesizing, the crowdfunding offering. Also, the Regulation $\mathrm{D}$ integration safe harbor protects only in instances where the two offerings are six months or more apart. 
purchasers are accredited. ${ }^{24}$

The Commission has over time seemed to recognize the lack of any policy supporting the application of the integration concept and thus developed a number of integration safe harbors. ${ }^{25}$ The crowdfunding regulations and the accompanying release proposing those regulations, however, are woefully lacking in regard to this important matter. The Commission simply ignored this issue in its proposed crowdfunding regulations by providing no integration safe harbor protection for crowdfunding. Instead, curiously and inappropriately, the Commission in the release proposing the crowdfunding regulations merely states what is apparently its opinion that "we believe" there should be no integration. ${ }^{26}$

The Commission needs a crowdfunding regulation providing a complete two-way integration safe harbor for all crowdfunding offerings. Efficient access to capital for a small business issuer using the crowdfunding exemption requires that the small business at the same time be allowed to deal with potential investors in a face-to-face manner. ${ }^{27}$

\section{Protection from the Intermediary's Regulatory Failures}

Small business issuers relying on the exemption provided by the proposed crowdfunding regulation will also encounter the costs generated by the risk that the financial intermediary involved in the crowdfunding transaction is not compliant with the Crowdfunding Act and the crowdfunding regulations. Both the Act itself and the crowdfunding regulations predicate the crowdfunding exemption on a "transaction [that] is conducted through [an intermediary] . . . that complies with the requirements of ...." the Crowdfunding Act. ${ }^{28}$

The impact of this will require the issuer to take steps to ensure that the intermediary has complied with all the steps necessary to meet the requirement of a "broker" or a "funding portal". The amount of investigation the issuer takes in order to ensure that the intermediary is compliant with the Crowdfunding Act will certainly be based on a cost benefit analysis by the small business issuer. The cost to the small business issuer will include both the out of pocket expenses of any investigation and the residual negative value remaining after investigation that, notwithstanding the investigation, the intermediary does not actually meet the statutory requirements. Both

\footnotetext{
${ }^{24}$ Campbell, Integration Doctrine, supra note 20, at 319-324 (providing examples demonstrating the nonsense of applying integration in exempt offerings).

${ }^{25}$ For a discussion of the Commission's regulatory integration safe harbors, see Campbell, Integration Doctrine, supra note 20, at 311-319.

${ }^{26}$ Release No. 33-9470, p. 18 (Oct. 23, 2013).

${ }^{27}$ The Commission in its release proposing the crowdfunding regulations offered an approach to integration that could be helpful in developing a safe harbor. Crowdfunding, 78 Fed. Reg. 66,428, 66,432 (Nov. 5. 2013).

${ }^{28} 15$ U.S.C. $\S 77 \mathrm{~d}(6)(C)(2013) ; 17$ C.F.R. $\S 227.100(a)(3)(2013)$.
} 
amount to economic costs that must be absorbed by the issuer.

The Commission should eliminate or significantly reduce this cost through its crowdfunding regulations. ${ }^{29}$ Society gains essentially nothing by encouraging issuer expenditures to audit intermediary regulatory compliance. Intermediary compliance with the its statutory and regulatory obligations is best and most efficiently achieved by penalties on the intermediary for its compliance failures. Penalties on issuers for intermediary non-compliance are misdirected and unnecessarily increase relative offering costs for small businesses relying the crowdfunding exemption.

\section{E. Conclusions}

For the Crowdfunding Act to accomplish the goal of providing small business issuers an efficient access to external capital, the Commission must adjust its balance in the crowdfund disclosure requirements, providing a stepped disclosure regime that requires less disclosure for smaller crowdfund offers. The Commission also should provide an effective safe harbor from integration and offer small business issuers protection in the case of regulatory failures by an intermediary. These changes would help to provide inexpensive financial intermediation for small business issuers while at the same time appropriately providing protection for investors.

Sincerely,

Rutheford B Campbell, Jr.

Spears-Gilbert Professor of Law

University of Kentucky

College of Law

Lexington, Kentucky 40506

(859) 257-4050

\footnotetext{
${ }^{29}$ The proposed crowdfunding regulations provide that there will be no loss of the crowdfunding exemption for an "insignificant" violation of the conditions for the exemption. 17 C.F.R. $\$ 227.502$ (2013). While this provision is inadequate to provide issuers with needed protection, it may offer a sensible approach. For example, the Commission by regulation could provide that the issuer will not lose the crowdfunding exemption for the intermediary's regulatory failures, provided the issuer is acting in "good faith". Issuer "good faith" could be defined to be met by a certification by the intermediary to the issuer that the intermediary has met all of its statutory and regulatory requirements.
} 